\title{
EUROPEAN NEARSHORING INDEX - IS EASTERN EUROPE ATTRACTIVE FOR SWISS IT FIRMS?
}

\author{
Keller, F., Zoller-Rydzek, B.
}

Florian Keller, Benedikt Zoller-Rydzek / ZHAW School of Management and Law, Center for EMEA

Business, Stadthausstrasse 14, 8400 Winterthur, Switzerland.Email: florian.keller@zhaw.ch,

benedikt.zoller@zhaw.ch

\begin{abstract}
The main goal of this paper is to identify the major factors for the decision of Swiss IT service firms to nearshore their locations and to quantify their relative importance. Moreover, we develop an IT Nearshoring Index ranking the attractiveness of different European regions. We use a quantitative survey of 56 Swiss IT service firms that are either actively engaging in nearshoring or planning to nearshore parts of their business. Using the survey, we identified five main factors for the nearshoring location decision of Swiss IT firms: economic, labour, institutional, social and location. We pin down the relative importance (weights) of the aforementioned factors using the survey results and expert interviews. The labour factors (including labour costs on the one and the availability of skilled IT workforce on the other side) proved to be most important. We use the obtained weights to construct a (weighted) IT Nearshoring Index. Based on the IT Nearshoring Index, we find that in contrast to general belief, the most attractive locations cannot be found in Eastern Europe, but in Southern UK or Western Germany. The first is due to their high availability of IT workforce, the latter due to their cultural and geographical proximity. Eastern European regions can base their competitive advantage on offering attractive labour costs, but this cannot make up for the disadvantage of greater cultural and geographical distance to Switzerland.
\end{abstract}

Keywords: nearshoring, IT services, location choice, MNEs

JEL Classification: F23, L22, L23, L86, M16

\section{Introduction}

In the last several years, we have seen a rise in IT nearshoring activities of Swiss companies. For example, two major Swiss Banks are running large service and IT centres in Poland. Credits Suisses' "Centers of Excellence" in Wroclaw and Warsaw employ around 4'500 people, and UBS runs "Shared Service Centers" in Krakow and Wroclaw with around 3'500 employees (Imwinkelried, 2017). Kündig \& Müller (2019) report that Swisscom, the Swiss national telecom provider, announced the opening of an IT centre in the Netherlands. The discrepancies in these examples lead to the question of which European region would provide the best basis for a future nearshoring project of a Swiss IT services company. 
Whereas offshoring was for a long time mainly associated with manufacturing, the dramatic change of information technology in the last decades made the offshoring of services, and specifically IT services, much more feasible. Additionally, many Western European countries and Switzerland specifically faced a severe shortage of skilled IT workers, which also led to an upward pressure on the wage costs of IT workers. Many companies resorted to outsourcing and offshoring parts of their IT departments to locations with more favorable conditions. However, after a first wave of offshoring services especially to India (Agrawal et al., 2010), many companies became aware that geographical and cultural distance is a relevant success factor for IT offshoring projects. Therefore, they began to offshore to countries that combined a large supply of skilled IT workers at attractive labour costs and geographical as well as cultural proximity. This development was named nearshoring (Carmel \& Abbott, 2007; Stetten et al., 2010; Ellram, 2013). Consequently, Egger et al. (2018) haven proven empirically that most European firms have affiliated firms in close proximity to their headquarters. The IT sector in Switzerland is no exception to this trend. Litzke et al. (2015) have shown that not only are $42 \%$ of companies already using nearshoring strategies, but they are also considering the strategy for the future compared to offshoring.

In this context it is crucial to understand the different factors and determinants for the decision of Swiss IT firms to nearshore their locations. This leads to the following two research question:

RQ1: What are factors determining and shaping the offshoring location decision of Swiss IT firms?

RQ2: What is the relative importance these factors?

To answer these research questions we employ a firm survey to identify the most important nearshoring factors. Additionally, we evaluate the relative importance of these factors and construct an IT Nearshoring Index. The IT Nearshoring Index pins down regions within Europe that are more attractive for Swiss IT firms and helps to point out the underlying reasons. Understanding regional heterogeneity will enable firms to strategically select their nearshoring location, to maximize their comparative advantage, and to gain competitiveness in global markets.

The examples of Swiss banks UBS and Credit Suisse described above, as well as the experience from previous manufacturing nearshoring, lets us assume that the Eastern European countries are prime locations for service offshoring. ${ }^{1}$ This leads to the following hypothesis:

The Eastern countries are the most attractive nearshoring locations (in Europe) for Swiss IT service firms.

We use the aforementioned IT Nearshoring Index to test this hypothesis.

\footnotetext{
${ }^{1}$ We follow the defiinition of the United Nations Statistical Division in which Eastern Europe consists of Belarus, Bulgaria, Czech Republic, Hungary, Poland, Republic of Moldova, Romania, the Russian Federation, Slovakia and Ukrain. Additionally we add the three Baltic states: Estonia, Latvia and Lithuania.
} 
In the literature, a firm's decision to off- or nearshore manufacturing traditionally depends on basic economic factors such as wage rates in the possible destination countries/regions or geographical distance between the headquarters and the possible location of the affiliate (Markusen, 2001; Navaretti \& Veneables, 2004). Offshoring of services is fundamentally different from the offshoring of manufacturing, as most services are provided face-to-face and often require specific knowledge, which is hard to codify. To this end, Nonaka \& Takeuchi (1995), Audia et al. (2001), and Bray (2007) point out that the transferability of knowledge is very important for firms and their organizational structure. Non-codifiable knowledge can be seen as intangible assets for firms. Better access to these intangible assets generates a comparative advantage for firms (Dierkes et al., 2003; Buckley \& Casson, 2016). Siegel et al. (2013) argue that cultural distance is an important obstacle for firms to transfer intangible assets or non-codifiable knowledge to foreign affiliates. Thus, cultural components are an important factor for firms when considering the location of an affiliate (Jarvenpaa \& Leidner, 1998; Boh et al., 2007). Therefore, the aforementioned IT Nearshoring Index does not only incorporate classical economic factors, such as market opportunities or corporate taxes in possible nearshoring destinations, but also includes soft components such as cultural distance measures, which are even more relevant for off- and nearshoring.

In our survey we find that Swiss IT firms' decision for location is mainly driven by labour market factors, more specifically by the availability of skilled IT workers. General economic factors, such as market size or taxes, are not as important. Intuitively, the local market size for IT services does not matter as much as the ability to offshore these services which in and of itself makes them easily tradeable. Thus, these services do not need to be consumed in local markets, making them less dependent on local market size. Moreover, cultural factors and specifically cultural distance are important for Swiss IT service firms' nearshoring decision, reflecting the importance of non-codifiable knowledge for IT services. In general, our overall IT Nearshoring Index indicates that the most attractive regions are either neighbouring to Switzerland or are easily reachable metropolitan areas, i.e. London, Berlin, Hamburg and Madrid. Geographically we observe two clusters: the South of the UK around London and Western Germany are most attractive. While the advantage of Western Germany is rooted mainly in geographical and cultural closeness, the UK cluster dominates through its availability of highly skilled IT workers. Contrary to public perception, Eastern Europe is not overly attractive for Swiss IT firms looking to nearshore. This is due to social factors and geographical distance which constitute a great barrier for Swiss IT firms. Although wage levels are relatively low in almost all Eastern European regions, the supply of highly skilled IT workers varies dramatically between Eastern European regions. Consistently, we find that the most attractive Eastern European regions are the ones that are able to accumulate a substantial IT work force and are easy to reach from Switzerland, such as Central Poland (Warsaw).

The remainder of the paper is structured as follows. After the introduction in Section 1, we describe the construction of the overall IT Nearshoring Index and its five sub-indices in Section 2. Additionally, we give details about the data collection process. We answer our research questions as well. In Section 3 we describe each sub-index in more detail. Section 4 gives an overview of the data and presents the actual nearshoring index and its different components. We test our hypothesis and briefly explain the impact of a possible Brexit on our IT Nearshoring Index. Finally, in Section 5 we conclude. 


\section{Methodical approach and data collection}

The IT Nearshoring Index reflects various dimensions of the decision of Swiss IT service firms to nearshore some of their activities. To identify the relative importance of different determinants, the Center of European Business at the ZHAW School of Management and Law in cooperation with swissICT, the largest association in the Swiss IT industry, and ISSS (Information Security Society Switzerland), the leading association in the Swiss IT Security industry, conducted a survey among Swiss IT service firms. The questionnaire used in the firm survey consisted of 34 questions regarding general information about the firm (number of employees, revenues, etc.), the nearshoring experience (currently engaging in nearshoring, in which countries, etc.), and, most importantly, the importance of different factors for the nearshoring decision of the firm. ${ }^{2}$ We received 56 high quality responses. $82 \%$ (46 firms) of the responding firms are actively engaging in nearshoring in various destinations in Europe. About $41 \%$ of all firms have more than 100 employees and a quarter have revenues exceeding USD 50 million. In the questionnaire, firms were asked to rate the importance of different factors for their nearshoring decision on a scale of 1 to 7 , with 1 being not important at all and 7 very important. We asked the respondents to directly rate the importance of factors such as the economic potential of a region, the availability of skilled IT workers in a region, and the cultural distance between a region and Switzerland. Based on these questions and the answers, we were able to answer the RQ1 and to identify 5 major determinants of the nearshoring decisions of firms. We commonly refer to these determinants as pillars of our IT Nearshoring Index: economic, labour, institutional, social and location pillar. Each pillar is created by weighting several variables that are associated with the respective pillar, i.e. matched by the underlying survey question. The overall IT Nearshoring Index consists of a weighted average of these five pillars. Figure 1 graphically depicts the stylized structure of the IT Nearshoring Index.

\section{Figure 1 | Construction of the IT Nearshoring Index}

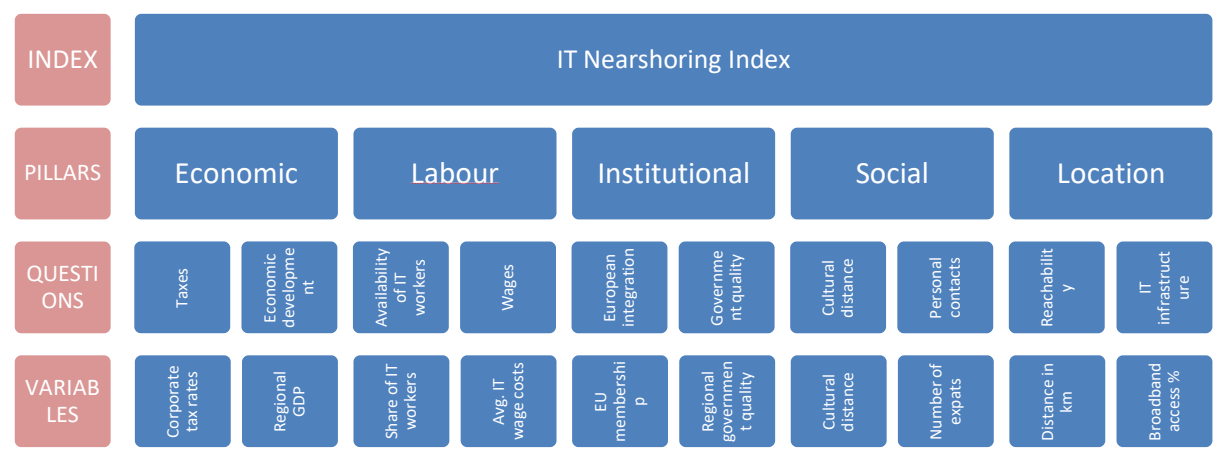

Source: authors

We used data from various sources, focusing on the Eurostat Nomenclature of Territorial Units for Statistics (NUTS) level 1 regions. The variables were chosen to match the underlying

${ }^{2}$ Most of these questions were multiple choice questions. 
questions of the survey. For example, firms were asked how important the market potential of the region is, which was meant to correspond with the variable of GDP and GDP per capita growths. Similarly, the reachability of a region was proxied by the distance in kilometers from Berne (Switzerland) and the number of airport passengers in the region. For each question, we identified a broad set of variables that could be used to describe the attractiveness of a region for IT service firms.

Focusing on Eurostat NUTS 1 regions allows a much finer distinction within countries, as regional variation and differences can be an important factor for a firm's decision to nearshore (Abbott \& Jones, 2012). If variables were only available at NUTS 2 level, we aggregated them, using population weights where appropriate. If only country level variables were available, we applied them to all NUTS 1 regions within the country. We always considered the last available year in the data, which most of the time was 2017 or 2018. Our main data source was the Eurostat regional database, which gives a broad set of variables at various NUTS levels. We provide an Online Appendix with detailed variable description and source information. ${ }^{3}$ In our data set some observations were missing for certain regions, which we filled in through a machine learning approach. Specifically, we employed multi-equation imputation of missing observations within each pillar using a random forest approach (Wulff \& Ejlskov, 2017). In total we have 50 variables assigned to the 5 pillars and we cover 115 NUTS 1 regions in Europe. While the Eurostat regional database is the most comprehensive source for detailed regional statistics, its coverage of countries is far from complete. Some interesting nearshoring destinations like Serbia, Ukraine, or Albania are missing due to the lack of reported data or differences in the data collection. However, as we will see later on, the main competitive advantages of these regions are not that crucial for Swiss IT companies. Therefore, we are confident, that these regions would not rank high in our index.

We used min-max and max-min approaches to create a comparable index of attractiveness for each variable in our data. The min-max and max-min approaches normalize the values of each variable between 0 and 100 , where 0 indicates the least attractive offshoring region and 100 the most attractive region for a firm. We use the following formula in the case that a higher numerical value of a variable indicates a higher attractiveness of the location:

$X_{I}=100 \frac{X-X_{\min }}{X_{\max }-X_{\min }}$,

where $X_{I}$ is the index value of an observation $X$ of a given variable, $X_{\max }$ and $X_{\min }$ give the maximum and minium value of the variable, respectively. The following formula is used if lower values indicate a higher attractiveness:

$X_{I}=100 \frac{X-X_{\max }}{X_{\min }-X_{\max }}$.

For example, the lowest wage for IT employees is paid in Northern Bulgaria (on average 4 EUR per hour), and this observation will receive a value of 100 . The highest wage for IT employees is paid in Sweden (on average 40 EUR per hour) and consequently this

\footnotetext{
${ }^{3}$ The Data Online Appendix is available at data.bzoller.com
} 
observation receives a value of zero. Index values for observations between these two extremes are linearly interpolated.

We used the survey results to assign weights that reflect the relative importance of each variable within a pillar. As variables are linked to certain questions in the survey, we were able to apply the rank sum method as proposed by Danielson \& Ekenberg (2017) to compute relative weights for each question and the corresponding variable based on the average importance value given by the Swiss IT firms in the survey. Relying on the rank sum implies that the rank order is directly reflected in the assigned weights. Specifically, the weight is calculated using the following formula:

$w_{i}=100 \frac{N+1-i}{\sum_{j}^{N}(N+1-j)}$

where $w_{i}$ indicates the weight of a question $i$ in a specific pillar. We ordered the questions within each pillar by their average importance, with the question with the highest average importance being indicated by $i=1$, the question with the second highest average importance rating being $i=2$, and so on. Thus $i$ does not only indicate a specific question, but also its rank within the pillar. $N$ gives the number of questions within a specific pillar. For example, the economic pillar consists of 4 questions, $N=4$. The question with the highest average importance rating refers to the access to local credits, $i=1$. According to the formula, access to credit or the ease of obtaining credit variable has a weight of $40 \%$ within the economic pillar. The second ranked question considers the general economic environment (inflation and exchange rate stability) and, using the formula, yields a weight of $30 \%$.

If more than one variable was assigned to a question, the importance weight was equally split between all assigned variables. Thus, each pillar was computed as the weighted importance of the underlying questions. Next, we weighted the pillars among each other to create the overall IT Nearshoring Index. We conducted expert interviews to obtain weights for the different pillars similar to our firm survey. Experts were asked to rank the relative importance directly in percentage. Thus, in the presented IT Nearshoring Index, we do not use the rank sum method to assign weights to each pillar, but, rather, the direct relative importance weights provided by the experts. We feel confident that, after an extensive briefing of the experts, their importance valuation is truly a reflection of the relative importance and not a rank importance. Table 1 gives the relative importance weight directly obtained from the experts and, for comparison, the corresponding rank sum weights for each pillar. In this case the rank is based on the (unweighted) average importance of all questions that constitute the pillar. 
Table 1 | Expert rating of relative importance of each pillar.

\begin{tabular}{|l|r|r|}
\hline & Relative importance & Rank sum weight \\
\hline Economic pillar & $17.35 \%$ & $6.66 \%$ \\
\hline Location pillar & $19.91 \%$ & $26.66 \%$ \\
\hline Social pillar & $19.21 \%$ & $13.33 \%$ \\
\hline Institutional pillar & $19.76 \%$ & $20.00 \%$ \\
\hline Labour pillar & $23.85 \%$ & $33.33 \%$ \\
\hline
\end{tabular}

Source: authors

Using the rank sum weight gives, by assumption, a much smaller weight to the lowest ranked pillar, in our case the economic pillar. This does not fully reflect the relative importance. As mentioned above, the interviewed experts were aware of the significance of the relative importance, while this fact was not clear for the participants of the survey. Using the rank sum weights changes the order of regions in the IT Nearshoring Index only slightly, i.e. UK regions will be even more dominant and Eastern European regions will be further down in the ranking. In the end, the weighting approach gives us the relative importance of the previously identified determinants of the nearshoring decision, which answers RQ2.

\section{Pillar description}

In this section we describe the 5 pillars of the IT Nearshoring Index in more detail and explain why each pillar matters for Swiss IT service firms. We describe only selected variables but mention all survey questions that constitute a pillar. We provide a more detailed description of the variables and sources in an Online Appendix. ${ }^{4}$

\subsection{Institutional pillar}

The institutional pillar reflects political factors and their direct consequences for the offshoring decision. For example, it includes the regional quality of government given by Charron et al. (2015) to indicate ease of doing business and dealing with the government in that specific region. We assume that better institutions decrease the costs of doing business in a region as well as political uncertainty, thus creating a more stable economic environment.

In the survey, respondents were asked to rate the importance of IP protection and data privacy laws, ease of doing business, openness towards foreign investment, and political stability.

\subsection{Location pillar}

The location pillar refers more generally to the geographical factors of the decision to nearshore. We include, for example, the distance in kilometers between the potential nearshoring region and Bern - which is located in the center of Switzerland - or the number of airport passengers in a region to reflect the reachability of a region. Egger et al. (2018) have shown that physical distance and communication barriers represent obstacles for firms

\footnotetext{
${ }^{4}$ The Data Online Appendix is available at data.bzoller.com
} 
when engaging in international business. Variables reflecting transportation infrastructure and the reachability of a region have the highest weight within this pillar.

In the survey, respondents were asked to rate the importance of geographical reachability of a region, time zone, property rights, ICT infrastructure, language and communication, as well as physical attractiveness of a region.

\subsection{Economic pillar}

The economic pillar considers direct economic measures. These can often be independent of institutions. For example, we include labour and corporate income taxes in this pillar, which are clearly an institutional/political outcome, but their value is not fully explained by institutional factors, i.e., France has good and high-quality institutions and rather high corporate and labour tax rates. On the other hand, institutions in The Netherlands are equally good, but corporate tax rates are much lower. Our survey indicates that economic factors are most important for Swiss IT firms in this pillar, thus the variables with the highest weight are inflation and stability of the currency exchange rate.

In the survey, respondents were asked to rate the importance of corporate taxes, the general economic environment, the market potential of the region, and access to financial markets.

\subsection{Labour pillar}

The labour pillar reflects various dimensions of the local labour market. Specifically, IT labour supply and demand factors, as well as labour costs factors. Obviously, firms want to offshore to destinations with a high supply of skilled IT workers, which makes it easier to fill open vacancies. On the other hand, labour costs should be low, which raises the profitability of the nearshoring venture. For Swiss IT service firms, the supply of skilled IT workers is much more important than the actual labour costs. Thus, the labour market tightness and supply of IT workers in a region receive the highest weights in this pillar.

In the survey, respondents were asked to rate the importance of availability of IT workers, the quality of IT workers, and the labour costs in a region.

\subsection{Social pillar}

In the social pillar we consider all kinds of social factors that might affect a firm's decision to nearshore. Foremost, cultural distance is an important factor and an often underestimated obstacle for firms operating in foreign markets. Research has shown that capabilities to use and to adjust to cultural differences is firm-specific, however it was not possible to include these firm-specific dimension in our general social pillar. Thus, we included a broader measure of social factors at the regional level, as we assume that general cultural closeness facilitates the cultural adjustments on average. Specifically, we include a cultural distance measure of the region relative to Switzerland (as a whole country), which is taken from Kaasa et al. (2013), or language proximity taken from Melitz \& Toubal (2014). Note that as Switzerland has four official languages and can be divided into 3 major cultural areas (French, Italian, and German speaking regions), the cultural distance and language measures reflect a Swiss average. 
In the survey, respondents were asked to rate the importance of cultural distance, personal contacts, and personal safety.

\section{Results}

In this section, we first give a general overview of the data and the different pillars and present the overall IT Nearshoring Index. We test the hypothesis from Section 1 and discuss how Brexit would affect the attractiveness of British regions within our IT Nearshoring Index.

The IT Nearshoring Index consists of five pillars that describe specific dimensions of the attractiveness of a possible nearshoring location for Swiss IT service firms. As all variables that constitute a pillar are normalized to an index between 0 and 100, the weighted average of these variables also has to be between 0 and 100. Table 2 shows the summary statistics of the five pillars and the overall IT Nearshoring Index, where variables have been weighted as described in Section 3 and the (relative importance) weights for the overall nearshoring index are given in Table 1.

Table 2 | Summary statistics of the 5 pillars and the nearshoring index.

\begin{tabular}{|l|r|r|r|r|r|r|}
\hline & \multicolumn{1}{|l|}{$\begin{array}{l}\text { Economic } \\
\text { pillar }\end{array}$} & \multicolumn{1}{l|}{$\begin{array}{l}\text { Location } \\
\text { pillar }\end{array}$} & $\begin{array}{l}\text { Social } \\
\text { pillar }\end{array}$ & \multicolumn{1}{l|}{$\begin{array}{l}\text { Institutional } \\
\text { pillar }\end{array}$} & \multicolumn{1}{l|}{$\begin{array}{l}\text { Labour } \\
\text { pillar }\end{array}$} & \multicolumn{1}{l|}{$\begin{array}{l}\text { Overall } \\
\text { index }\end{array}$} \\
\hline Mean & 58.16 & 60.95 & 48.62 & 59.73 & 46.00 & 54.23 \\
\hline Minimum & 40.05 & 27.34 & 14.78 & 28.60 & 2.52 & 27.99 \\
\hline Maximum & 73.06 & 84.92 & 74.52 & 86.48 & 74.15 & 68.99 \\
\hline Median & 57.26 & 61.75 & 51.06 & 65.47 & 45.94 & 57.16 \\
\hline Variance & 5.86 & 18.95 & 14.95 & 23.04 & 24.82 & 92.64 \\
\hline Obs. & 115 & 115 & 115 & 115 & 115 & 115 \\
\hline
\end{tabular}

Source: authors

Figure 2 | Whisker plot of the IT Nearshoring Index and its 5 pillars.

Whisker plot for Nearshoring Index Pillars

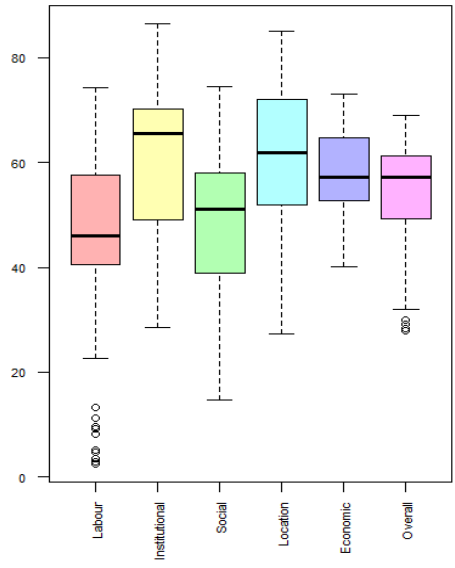

Source: authors 
In general, we observe substantial regional heterogeneity within the five pillars and the overall index. Figure 2 depicts a whisker plot for each of the pillars and the overall IT Nearshoring Index. In the plot, the distribution of the region index values is described by a whisker for each pillar. The rectangular box of the whisker gives the interquartile range of the underlying data and the bold horizontal line indicates the median value. The longer the rectangular box, the more dispersed the pillar index values between different regions. The upper and lower bound of the whisker are given as 1.5 times the interquartile range and the dots are outlier NUTS 1 regions.

Especially in the labour, institutional, and location pillars, we see a considerable dispersion, indicating that some NUTS 1 regions perform very well in these dimensions, while others do not at all. In general, the institutional quality seems rather high (median is over 65), which is not surprising as most countries are members of the European Union, which ensures certain institutional standards. Similarly, the location pillar has a high average and median as Switzerland is located very much in the center of Europe and geographical distance has a high weight in the pillar. The labour pillar has the lowest mean and median and, as indicated by the dots in the lower part, the most outliers of the 5 pillars. This is due to the very low supply of IT workers in some rural regions, mainly in the European periphery.

Table 3 shows the Pearson correlation coefficient for the 5 pillars and the overall IT Nearshoring Index. Clearly, and by construction, the overall nearshoring index is positively correlated with all 5 pillars but the correlation between the different pillars varies considerably. Some pillars are only weakly correlated, such as the economic pillar and the location pillar, while others are very strongly correlated, such as the social and institutional pillar. This partly reflects the interdependence of the pillars and the underlying data generating process

Although the pillars are not independent or orthogonal in a statistical sense, the limited correlation between most pillars indicates that the different pillars indeed indicate different factors of the nearshoring decision of Swiss IT firms.

Table 3 | Pearson correlation coefficient of the 5 pillars and the overall nearshoring index

\begin{tabular}{|l|r|r|r|r|r|r|}
\hline & \multicolumn{1}{|l|}{$\begin{array}{l}\text { Economic } \\
\text { pillar }\end{array}$} & $\begin{array}{l}\text { Location } \\
\text { pillar }\end{array}$ & $\begin{array}{l}\text { Social } \\
\text { pillar }\end{array}$ & $\begin{array}{l}\text { Institutional } \\
\text { pillar }\end{array}$ & $\begin{array}{l}\text { Labour } \\
\text { pillar }\end{array}$ & $\begin{array}{l}\text { Overall } \\
\text { Index }\end{array}$ \\
\hline Economic pillar & 1.000 & 0.171 & -0.036 & 0.118 & 0.294 & 0.326 \\
\hline Location pillar & 0.171 & 1.000 & 0.800 & 0.817 & 0.322 & 0.881 \\
\hline Social pillar & -0.036 & 0.800 & 1.000 & 0.731 & 0.110 & 0.735 \\
\hline Institutional pillar & 0.118 & 0.817 & 0.731 & 1.000 & 0.346 & 0.872 \\
\hline Labour pillar & 0.294 & 0.322 & 0.110 & 0.346 & 1.000 & 0.656 \\
\hline Overall Index & 0.326 & 0.881 & 0.735 & 0.872 & 0.656 & 1.000 \\
\hline
\end{tabular}

Figures 3 to 7 plot maps for each of the five pillars. Regions with high index scores in the respective pillar are darker, while regions with low scores are lighter. Economic factors are more favorable in Central Europe, the UK, and Eastern Europe, while firms face rather unfavorable conditions in Southern Europe and France. Many of the regions in Southern Europe still have not fully recovered from the European debt crisis in 2009, implying lower market potentials in these regions. While the institutional factors are very good in most 
European countries, the Scandinavian countries stand out above all. On the other hand, many South-Eastern European regions are unattractive for nearshoring as their institutions are weaker by comparison to most other European regions. As already indicated in Table 3, the location and social pillar are highly correlated. Specifically, regions that are geographically closer to Switzerland have higher scores in the location and social pillar. This is consistent with the findings of Argote \& Ingram (2003) and Argote et al. (2012). In terms of the labour market pillar, we observe the opposite; regions that are more peripheral are more competitive. Eastern Europe and specifically Poland combine low wages with a large IT workforce, making it very attractive for Swiss IT firms. This holds as well for countries such as Spain and Portugal. We provide detailed interactive graphs and the complete ranking of the IT Nearshoring Index in an Online Appendix. ${ }^{5}$

Figure 3 | Map of economic pillar

\section{Economic Pillar}

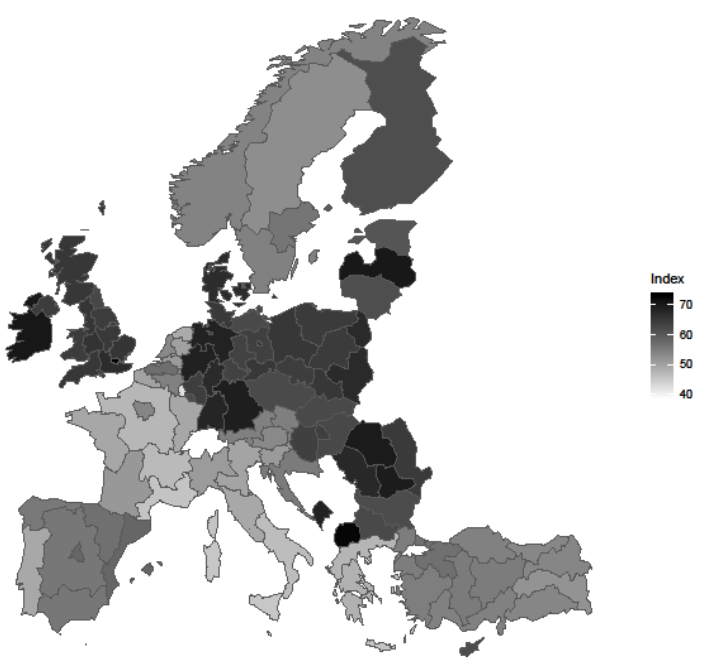

Source: authors

${ }^{5}$ The interactive graphs Online Appendix is available at nearshoring.bzoller.com 
Figure 4 | Map of the institution pillar

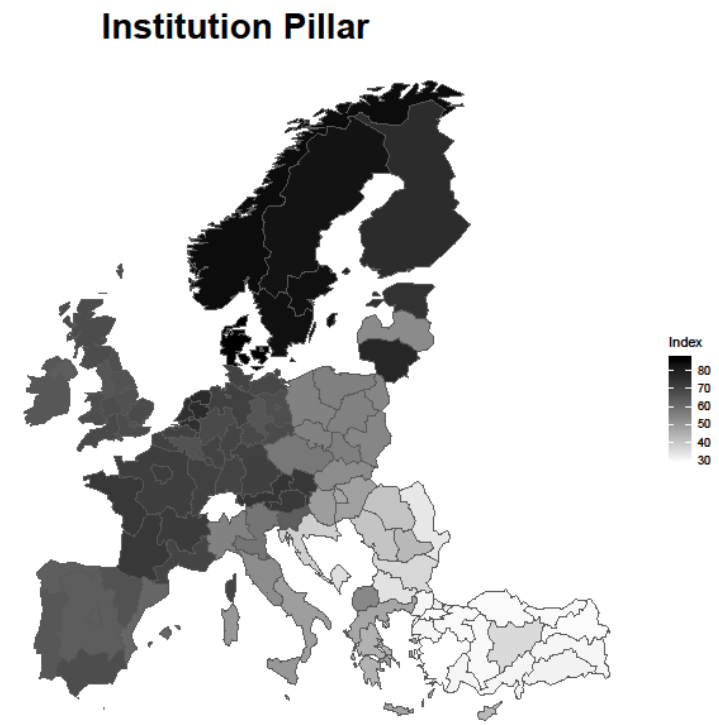

Source: authors

Figure 5 | Map of the location pillar

\section{Location Pillar}

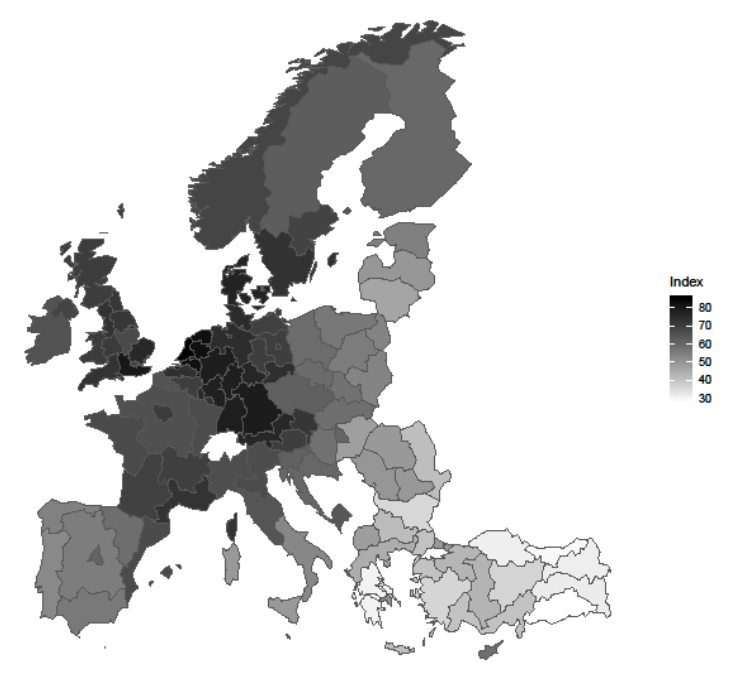

Source: authors 
Figure 6 | Map of the social pillar

\section{Social Pillar}

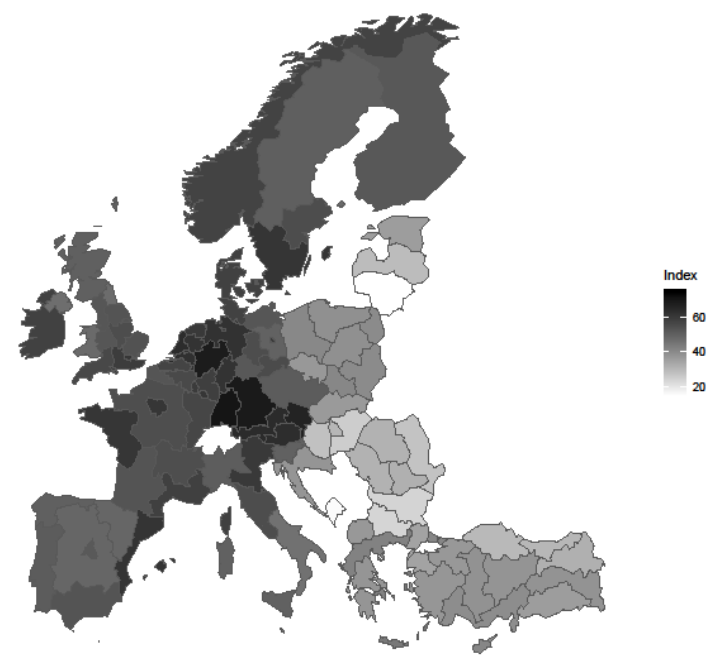

Source: authors

Figure 7 | Map of the labour pillar

\section{Labour Pillar}

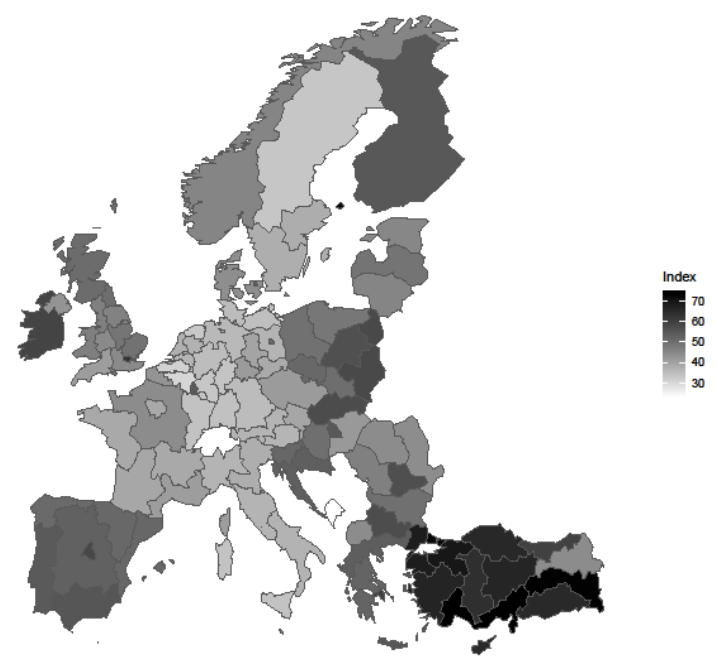

Source: authors

Figure 8 shows the overall IT Nearshoring Index. London and the surrounding regions are most attractive for Swiss IT firms but Southern and Western German regions also rank very high. In Southern Europe, Madrid and Catalonia (Barcelona) are favorable locations. Most regions in Eastern and South-Eastern Europe are not very attractive nearshoring locations for Swiss IT firms. In general, it seems that greater metropolitan areas such as London, Berlin, 
Hamburg, or Madrid are more successful at attracting a sizable pool of IT workers, due at least partly to the ease in reaching them. Tables 4 and 5 show the Top 10 regions of the overall IT Nearshoring Index and the Top 10 Eastern European regions in the overall index, respectively. By a wide margin, London is the most attractive location for Swiss IT service firms in Europe. Most other regions on the Top 10 are rather close to each other. The highest ranked Eastern European region is Central Poland in which Warsaw and Łódź located. These are the biggest and third biggest cities in Poland. A good supply of skilled workers from local universities, relatively low wages, and the access to an international airport make Central Poland an attractive location for IT firms.

Figure 8 | Map of the overall IT Nearshoring Index.

\section{IT Nearshoring Index}

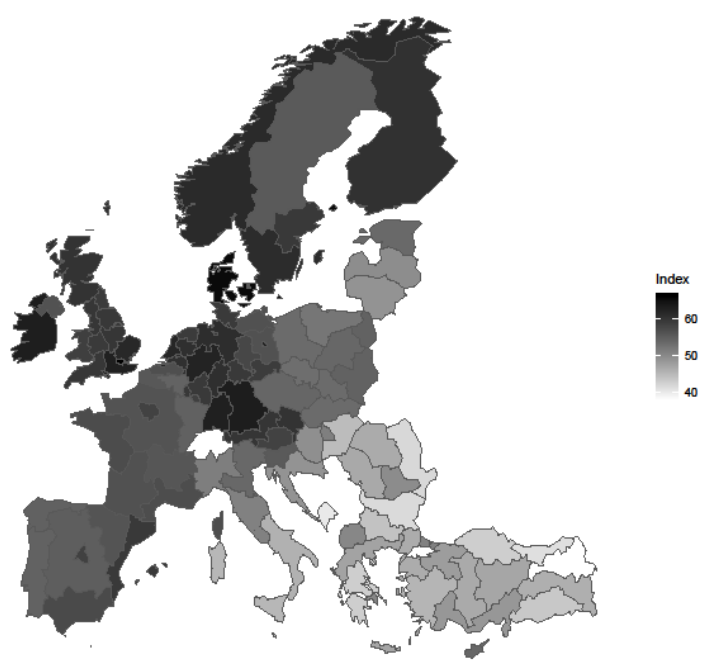

Source: authors

Table 4 | Top 10 regions to nearshore for Swiss IT service firms

\begin{tabular}{|l|l|l|r|}
\hline Rank & Region & Country & Overall Index \\
\hline 1 & London & United Kingdom & 69 \\
\hline 2 & South East UK & United Kingdom & 65.2 \\
\hline 3 & Bavaria & Germany & 64.8 \\
\hline 4 & Berlin & Germany & 64.4 \\
\hline 5 & Denmark & Denmark & 64.4 \\
\hline 6 & East of England & United Kingdom & 64.4 \\
\hline 7 & Baden-Württemberg & Germany & 64.2 \\
\hline 8 & North Rhine-Westphalia & Germany & 64.1 \\
\hline 9 & Hamburg & Germany & 63.8 \\
\hline 10 & Ireland & Ireland & 63.7 \\
\hline
\end{tabular}

Source: IT Nearshoring Index 2018, authors' own calculations 
Table 5 | Top 10 Eastern European regions to nearshore for Swiss IT service firms

\begin{tabular}{|l|l|l|r|}
\hline Rank & Region & Country & Overall Index \\
\hline 60 & Central Poland & Poland & 56.1 \\
\hline 62 & Wschodni & Poland & 55.8 \\
\hline 63 & Poludniowy & Poland & 55.4 \\
\hline 65 & Pólnocno-Zachodni & Poland & 55.4 \\
\hline 69 & Poludniowo-Zachodni & Poland & 55.1 \\
\hline 70 & Slovenia & Slovenia & 54.6 \\
\hline 73 & Pólnocny & Poland & 54.0 \\
\hline 75 & Budapest & Hungary & 53.6 \\
\hline 77 & Slovakia & Slovakia & 53.2 \\
\hline 78 & Estonia & Estonia & 53.0 \\
\hline
\end{tabular}

Source: IT Nearshoring Index 2018, authors' own calculations

In our hypothesis we stated that the Eastern European countries are the most attractive nearshoring locations for Swiss IT service firms. We used a standard student t-test to test our hypothesis (see Table 6). It compares the means of the Top 10 regions of the overall IT Nearshoring Index and the Top 10 Eastern European regions in each pillar. In 4 out of the 5 pillars, the Top 10 Eastern European regions' average score is significantly lower than the average of the Top 10 overall regions. The location and social pillar have the highest difference. This does not come as a surprise: geographically Eastern European regions are farther away and harder to reach than most Western European regions. The Top 10 Eastern European regions perform well on the labour market dimension, where their average index rank is not significantly different from the Top 10 overall regions. This is mainly based on the labour cost advantage of Eastern European regions. The survey of Swiss IT firms indicates that the supply of skilled IT workers is the most important factor for the outsourcing decision of firms (average importance score of 6.33 out of 7 ). It is much more important than labour costs, which have an average importance of 5.86. Thus, for most Eastern European regions it will be more important to attract skilled IT workers than to compete with low labour costs. Economic and institutional factors matter, but their overall impact on explaining the lower attractiveness of Eastern European regions is relatively small. In this light, we can reject our hypothesis that Eastern European countries/regions are the most attractive location for Swiss IT service firms. 
Table 6 | Difference between Top 10 overall regions and the Top 10 Eastern European regions

\begin{tabular}{|l|r|r|r|r|r|r|}
\hline & \multicolumn{1}{|l|}{$\begin{array}{l}\text { Economic } \\
\text { pillar }\end{array}$} & \multicolumn{1}{l|}{$\begin{array}{l}\text { Location } \\
\text { pillar }\end{array}$} & \multicolumn{1}{l|}{$\begin{array}{l}\text { Social } \\
\text { pillar }\end{array}$} & \multicolumn{1}{l|}{$\begin{array}{l}\text { Institutional } \\
\text { pillar }\end{array}$} & \multicolumn{1}{l}{$\begin{array}{l}\text { Labour } \\
\text { pillar }\end{array}$} & \multicolumn{1}{l|}{$\begin{array}{l}\text { Overall } \\
\text { index }\end{array}$} \\
\hline Top 10 (avg. index) & 68.2 & 74.9 & 62.0 & 70.1 & 51.7 & 64.80 \\
\hline $\begin{array}{l}\text { Top 10 EE (avg. } \\
\text { index) }\end{array}$ & 62.5 & 57.5 & 38.9 & 56.8 & 57.2 & 54.61 \\
\hline Difference & 5.7 & 17.4 & 23.2 & 13.3 & -5.5 & 10.18 \\
\hline t-value & 3.360 & 10.037 & 9.845 & 4.454 & -1.272 & 17.04 \\
\hline p-value & 0.004 & 0.000 & 0.000 & 0.000 & 0.220 & 0.000 \\
\hline
\end{tabular}

Difference between the Top 10 overall regions and Top 10 Eastern European regions based on the average index values of the 5 pillars and the overall index. Two-sided student t-test, equal variance.

Source: IT Nearshoring Index 2018, authors' own calculations.

Lastly, we can create a counterfactual IT Nearshoring Index to account for the impact of a possible Brexit on the attractiveness of UK regions. Leaving the European Union would decrease the IT Nearshoring Index score for every UK region by about 2.4 points. While London would still be the most attractive location for Swiss IT service firms, the second ranked South East UK region drops out of the Top 10 to rank 11. The ranking for the highest ranked Central European region - Central Poland - would not increase at all after a possible Brexit, as the lowest ranked UK region - Northern Ireland - is ranked 46 with an IT Nearshoring Index score of 58.8. In general, we find that Brexit would hit the UK regions which are already not ranked very high relatively harder than those that are ranked high.

The IT Nearshoring Index is consistent with common findings in the literature. Smite et al. (2013) use case studies to identify different factors that influence the location decision of IT service firms. Among the most important factors are labour costs and resource availability. They also point out that not only geographical distance has a negative effect for the location choice of IT firms, but also cultural distance. With our IT Nearshoring Index, we provide a quantitative framework that incorporates all these factors. Thus, the IT Nearshoring Index actually reflects the firm trade-offs described by Carmell \& Abbott (2007), i.e. a multidimensional measure of distance (geographical and cultural) is weighted against classical economic factors such as wages and availability of workers. This is also reflected in the low correlation between the economic pillar and the social pillar shown in Table 3. Moreover, we explicitly consider within-country heterogeneity, which can be an important reason for competitive advantages as pointed out by Abbott \& Jones (2012) relying on two case studies. Lastly, the weighting of the IT Nearshoring index is consistent with the empirical findings of Ellram et al. (2013) and Egger et al. (2018). The former uses a regression analysis and find that the factors with the highest loadings are the availability of local management and labour, but also geographical distance and economic factors.

\section{Conclusion}

In this article we presented an IT Nearshoring Index for Swiss IT firms. We used a survey among Swiss IT firms to identify 5 important determinants of the off- and nearshoring location decision of IT firms in Switzerland. Based on the survey results, we evaluated the relative importance of these determinants. The most important factor for Swiss IT firms is the regional labour market for IT professionals. Specifically, the availability of skilled IT workers in a 
possible nearshoring destination ranks with the highest importance in the survey. The reachability and cultural closeness are almost equally important for IT firms when choosing their nearshoring location. Direct economic factors, such as the possible market size are less important.

Based on these findings we constructed an IT Nearshoring Index and found that metropolitan areas are the most attractive destinations for Swiss IT firms. We identified two attractiveness clusters, the Southern UK around London and Western Germany. The former is due to the high availability of IT workers, while the latter is due to the good reachability and social closeness of the Southern German regions to Switzerland. Empirically we rejected our hypothesis that Eastern European countries are the most attractive locations for Swiss IT service firms. Although wages for IT workers in Eastern Europe are considerably lower than in Western Europe, it is not enough to compensate for the vast geographical and cultural distances of these regions. To increase the competitiveness of the region, governments could further strengthen the education in IT and therefore enlarge the availability of IT workers.

\section{Acknowledgement}

Research assistantship of Sandra Hubmann, Florian Elias, and Yannic Egly is greatly acknowledged.

\section{References}

Abbott, P., \& Jones, M. (2012). Everywhere and nowhere: Nearshore software development in the Context of Globalization. European Journal of Information Systems, 21(5), 529-551.

Agrawal, S., Goswami, K., \& Chatterjee, B. (2010). The Evolution of Offshore Outsourcing in India. Global Business Review, 11(2), 239-256.

Argote, L., \& Ingram, P. (2000). Knowledge Transfer: A Basis for Competitive Advantage in Firms. Organizational Behavior and Human Decision Processes, 82(1), 150- 169.

Argote, L., Denomme, C., \& Fuchs, E. (2012). Learning Across Boundaries: The Effect of Geographic Distribution. Handbook of Organizational Learning and Knowledge Management, John Wiley \& Sons, Inc, 659-684.

Audia, P. G., Sorenson, O., \& Hage, J. (2001). Tradeoffs in the Organization of Production: Multiunit Firms, Geographic Dispersion and Organizational Learning. Advances in Strategic Management, 18, 75-105.

Bray, D. A. (2007). Literature Review - Knowledge Management Research at the Organizational Level. Mimeo.

Buckley P. J., \& Casson, M. (2016). The Future of the Multinational Enterprise. In M. Augier, D., \& D. Teece (Eds.), The Palgrave Encyclopedia of Strategic Management. London, United Kingdom: Palgrave Macmillan.

Carmel, E., \& Abbott, P. (2007). Why 'Nearshore' means that Distance Matters. Communications of the $A C M, 50(10), 40-46$.

Charron, N., Dijkstra, L., \& Lapuente, V. (2015). Mapping the Regional Divide in Europe: A Measure for Assessing Quality of Government in 206 European Regions. Social Indicators Research, 122(2), 315-346. 
Danielson M., \& Ekenberg, L. (2017). Trade-Offs for Ordinal Ranking Methods in Multi-criteria Decisions. In D. Bajwa, S. Koeszegi, \& R. Vetschera (Eds.), Group Decision and Negotiation. Theory, Empirical Evidence, and Application (pp. 16-27). Cham, Switzerland: Springer.

Dierkes, M., Berthoin, A. A., Child, J., \& Nonaka, I. (2003). Handbook of Organizational Learning and Knowledge. New York, NY: Oxford University Press.

Egger, P. H., Riezmann, R., \& Zoller-Rydzek, B. (2018). Multi-Unit Firms and Their Scope and Location Decision. Mimeo.

Ellram, L., Tate, W., \& Peterson, K. (2013). Offshoring and Reshoring: An Update on the Manufacturing Location Decision. Journal of Supply Chain Management, 49(2), 14-22.

Ellram, L. M. (2013). Offshoring, Reshoring and the Manufacturing Location Decision. Journal of Supply Chain Management, 49(2), 3-5.

Eurostat Regional Database. Retrieved via API, March 02, 2019, from https://ec.europa.eu/eurostat/web/regions/data/database.

Farrell, D. (2004). Can Germany Win from Offshoring? New York, NY: McKinsey Global Institute.

Imwinkelried, D. (2017). Polen - das gelobte Land der Banken zeigt Überhitzungserscheinungen. Neue Zürcher Zeitung. Retrieved from https://www.nzz.ch/wirtschaft/polen-das-gelobte-land-derbanken-zeigt-ueberhitzungserscheinungen-Id.1319554.

Kaasa, A., Vadi, M., \& Varblane, U. (2013). European Social Survey as a Source of New Cultural Dimensions Estimates for Regions. International Journal of Cross Cultural Management, 13(2), 137-157.

Kündig, C., \& Müller, A. (2019). Swisscom will bis 200 IT-Jobs in Holland schaffen. Watson. Retrieved from https://www.watson.ch/digital/schweiz/795899762- swisscom-will-bis-200-it-jobs-

in-holland-schaffen.

Litzke, M., Schladitz, O., Pedron, C., \& Gysel, U. E. (2015). Vom Kosten zum Erfolgsfaktor, IT-SourcingManagement-Studie 2014/2015, ZHAW School of Management and Law. Mimeo.

Markusen, J. R. (2001). Contracts, Intellectual Property Rights, and Multinational Investment in Developing Countries. Journal of International Economics, 53(1), 189-204.

Melitz, J., \& Toubal, F. (2014). Native Language, Spoken Language, Translation and Trade. Journal of International Economics, 93(2), 351-363.

Navaretti, G. B., \& Venables A. J. (2004). Multinational Firms in the World Economy. Princeton, NJ: Princeton University Press.

Nonaka, I., \& Takeuchi, H. (1995). The Knowledge-Creating Company: How Japanese Companies Create the Dynamics of Innovation. New York, NY: Oxford University Press.

Siegel, J. I., Licht, A. L., \& Schwartz, S. H. (2013). Egalitarianism, Cultural Distance, and Foreign Direct Investment: A new Approach. Organization Science, 24(4), 1174-1194.

Smite, D., Wohlin, C., Aurum, A., Jabangwe, R., \& Numminen, E. (2013). Offshoring Insourcing in Software Development: Structuring the Decision-Making Process. Journal of Systems and Software, 86(1), 1054-1067.

Stetten, A. V., Beimborn, D., Kuznetsova, E., \& Moos, B. (2010). The Impact of Cultural Differences on IT Nearshoring Risks from a German Perspective. In R. Sprague (Ed.), Proceedings of the 2010 43rd Hawaii International Conference on System Sciences (HICSS). Washington, DC: IEEE Computer Society. 
Tate, W., Ellram, L., Schoenherr, T., \& Peterson, K. (2014). Global Competitive Conditions Driving the Manufacturing Location Decision. Business Horizon, 57(3), 381-390.

Trampel, J. (2004). To Offshore or Nearshore IT Services? An Investigation using Transaction Cost Theory. Mimeo.

Wulff, J., \& Ejlskov, L. (2017). Multiple Imputation by Chained Equations in Praxis: Guidelines and Review. Electronic Journal of Business Research Methods, 15(1), 41-56.

The research paper has been reviewed. | Received: May 29, 2019; Revised: August 2, 2019;

Accepted: August 22, 2019; Prepublished online: August 22, 2019; Published: October 1, 2019 